\title{
Geology of the Woods Hole Area, Massachusetts- The Story behind the Landscape
}

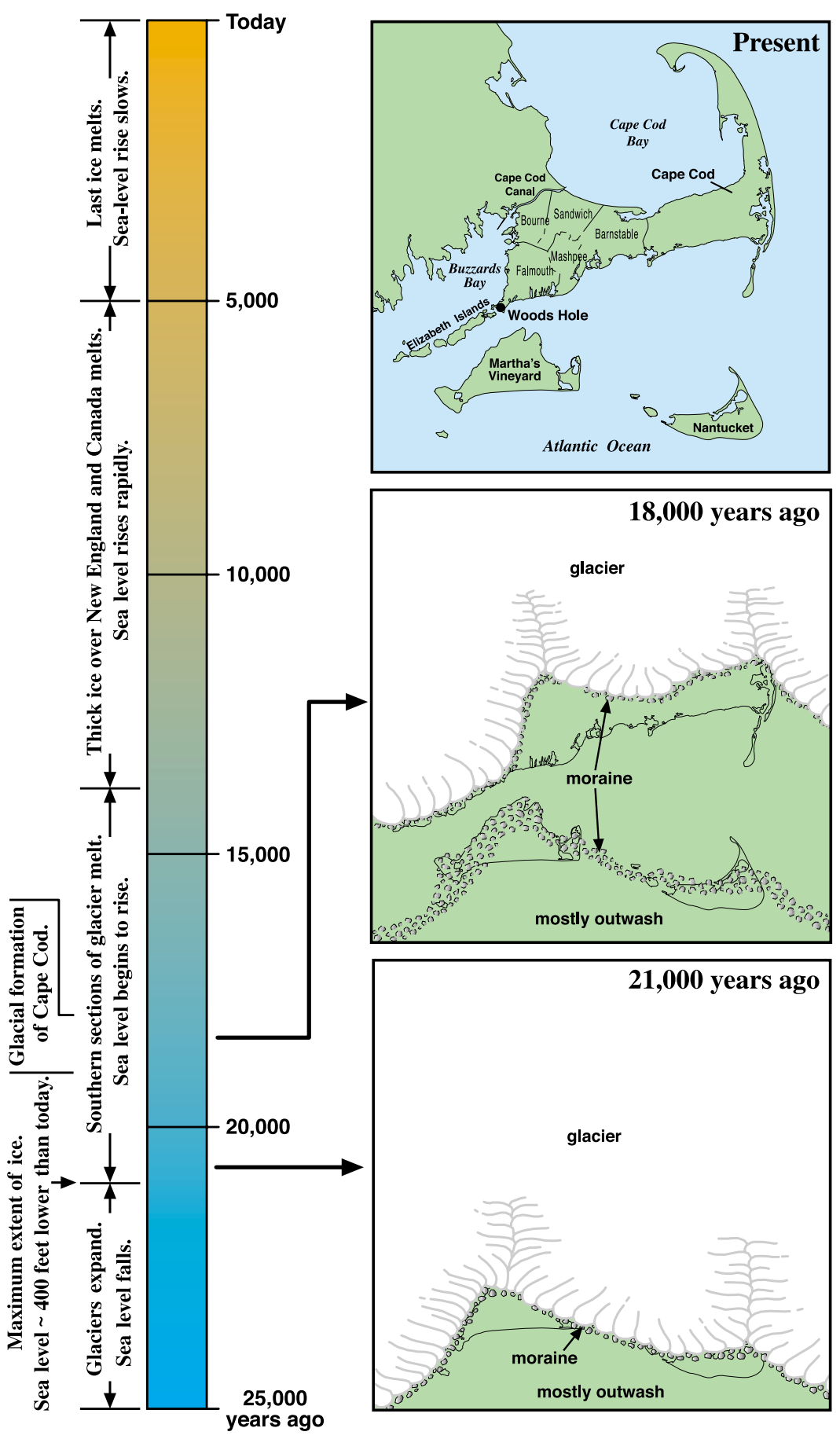

Figure 1. Ice front positions (moraines) on Cape Cod and nearby islands and timeline for glacial and sea-level changes in the last 25,000 years. The moraine across Martha's Vineyard and Nantucket roughly marks the maximum advance of the ice. The moraine across Cape Cod marks the youngest and most well preserved ice front position during glacial retreat. Data from R.N. Oldale, 1976, Geologic History of Cape Cod, Massachusetts, U.S. Geological Survey General Interest Publication.
The geologic story of the Woods Hole area, Cape Cod, Mass. (fig. 1), was written by glacial ice during the last ice age and edited by the ocean waves. If you learn to read today's landscape, you can see the fascinating history it records. The features of Cape Cod, from the ponds and cranberry bogs to the gently sloping sandy uplands and rocky, irregular hills to the beaches, result from the glacial processes that built the cape and the marine processes that still shape it.

Many geologists since the late 19th century have contributed to telling this story. The U.S. Geological Survey has studied the geology of Cape Cod in order to provide people with objective scientific data that can be applied to wise stewardship of the land and coasts.

\section{The Last Ice Age}

During the last ice age, between about 75,000 and 21,000 years ago, more snow fell over northern lands than melted each year. As the snow accumulated, it compacted into ice, eventually piling up into glaciers more than 2 miles thick. Although we think of ice as hard and brittle, it actually can flow through time under the pressure resulting from the weight of a glacier.

Glaciers began to flow radially outward from under the area of greatest ice accumulation, near Hudson Bay, Canada. This flowing ice scraped and polished the solid rock beneath it and carried along rocks and soil.

The glaciers were made of frozen water that could not return to the seas. As water continued to evaporate from the seas, fall as snow, and freeze into glaciers, worldwide sea level fell. By the time glaciers reached their maximum extent 21,000 years ago, sea level had fallen about 400 feet.

The leading edge of the glaciers eventually flowed far enough south that the ice warmed and began to melt. As the ice melted, it released water and rock debris, although the glacier continued to flow. The meltwater ran toward the sea, carrying and depositing sand and gravel to form gently sloping outwash plains. At times, the rates of melting and glacial flow were roughly equal so that the edge of a glacier stayed in one place. 
Large rocks and piles of broken and ground-up rocks accumulated in front of the glaciers and were pushed into moraine hills by occasional faster advances of the ice. At the ragged edges of glaciers, blocks of ice, separated by crevasses from the main body of the ice, were gradually buried by rock debris.

About 19,000 years ago, the climate warmed enough that the balance of snowfall and melting changed; the glaciers melted away in a few thousand years, leaving behind their burden of sand and rock as evidence of their passage. When buried blocks of ice melted, the sand and gravel over them collapsed into depressions called kettle holes. Global sea level rose as the previously frozen water ran back into the ocean. By 2,000 years ago, sea level was less than 10 feet lower than it is today; waves began to break against the new deposits and to erode and reshape the shoreline.

\section{Glacial Landscapes near Woods Hole}

The landscapes near Woods Hole show this glacial history. The line of hills that forms the Elizabeth Islands and that runs from Woods Hole north to the Cape Cod Canal and then east across Sandwich and Barnstable is a moraine (figs. 2, 3). Moraines are characterized by an irregular topography of hills and swales and an unsorted mixture of rock sizes, from giant boulders to silt and clay so fine that it is called rock flour. The village of Woods Hole sits on the moraine and on some young beach deposits.

West and North Falmouth are also on the moraine, but most of Falmouth is on the outwash plain. This land has a gentle gradient and a small range of grain sizes; it is mostly sand and gravel, and there are few rocks larger than a softball in the outwash and only small amounts of silt. Dotting both the outwash plain and moraine are variably sized kettle holes. Some big kettle holes contain ponds because they are deep and intersect the ground-water table; for example, Long Pond (fig. 2) has a maximum depth of 65 feet, more than 50 feet below sea level, and Great Harbor, Woods Hole, is 70 feet at its deepest point, which is deeper than Buzzards Bay to the north. Woods Hole channel is a string of deep kettle holes that cuts through the moraine hills.

The gently sloping land of East Falmouth and Mashpee is also outwash. These plains are cut by many narrow, straight valleys that were created by springs coming to the surface along the shore and cutting their way up the ground-water gradient soon after the glacier melted. These valleys intersect ground water, and so fresh water drains into them along their length, creating small streams like the Coonamesset River and watering cranberry bogs in the valley bottoms. The upper ends of most of these valleys are dry today. The southern ends of some of these valleys were flooded when sea level rose toward its current level, forming the narrow estuaries like Falmouth Harbor (fig. 2), Great Pond, and Green Pond on Falmouth's south shore.

\section{Effects of Rising Seas}

Once sea level rose to about its current level, the sea took over the shaping of the land. Waves eroded the sand and gravel of the outwash plains and the more resistant moraines, which contained rocks and silt. The sand removed from the glacial hills and plains was carried along the shore by the

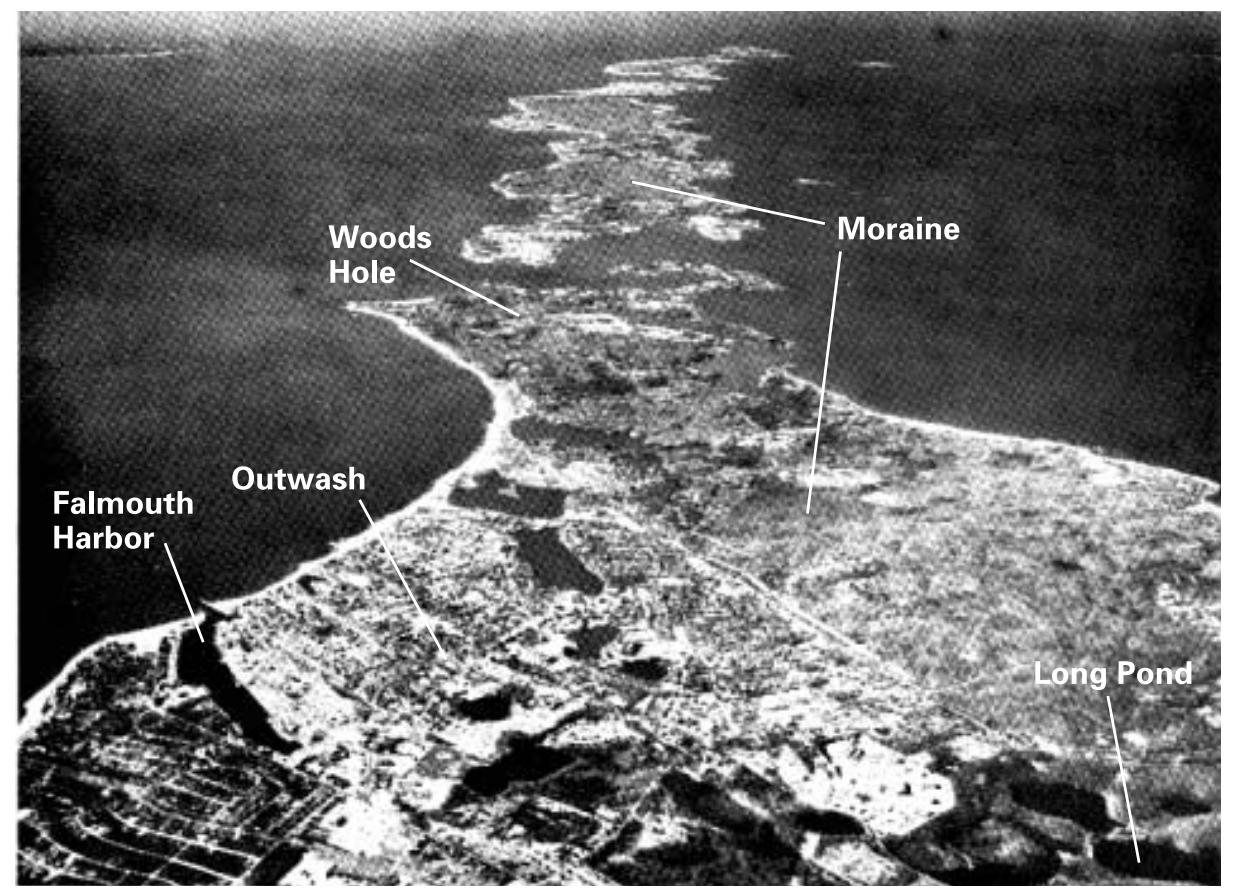

Figure 2. View southwestward over the Buzzards Bay moraine from Falmouth to the Elizabeth Islands, Mass., showing how the moraine (undeveloped) and outwash (developed) influenced settlement patterns in Falmouth. Photograph from Geology Illustrated, 1966, copyright John S. Shelton; used by permission.

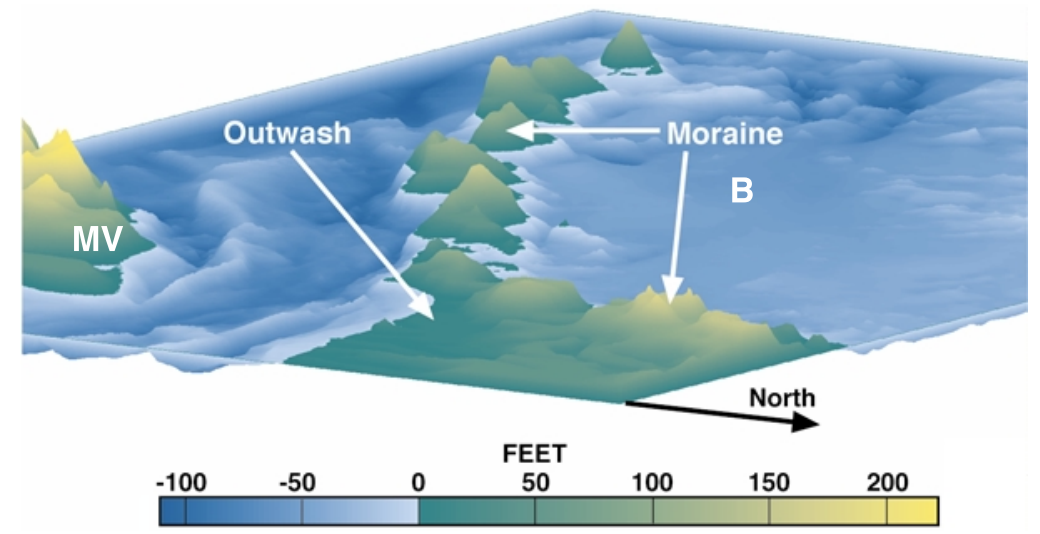

Figure 3. Computer image of the topography and bathymetry of Cape Cod, Buzzards Bay (B), and part of Martha's Vineyard (MV), showing how the morphology continues offshore. Vertical scale is exaggerated; see figure 2. 